\title{
Somatic Embryogenesis Pathways in Cultured Allium fistulosum Cells
}

\author{
Ki-Su Lee ${ }^{1}$ and Kanji Ono ${ }^{2}$ \\ ${ }^{1}$ Department of Natural Environmental Science, Graduate School, Kumamoto University, \\ Kumamoto 860-8555, Japan \\ ${ }^{2}$ Department of Biological Science, Faculty of Science, Kumamoto University, \\ Kumamoto 860-8555, Japan
}

Accepted August 9, 2000

\begin{abstract}
Summary The process of plant regeneration from cultured A. fistulosum cv. Fresh cells was investigated morphologically and histologically. Somatic embryogenesis was observed in one cell line (Yline) when cells maintained by suspension culture in liquid MS medium containing $0.5 \mathrm{mg} / 1$ 2,4-D were transferred into 2,4-D-free medium. Two somatic embryogenesis pathways were identified in Yline cells. Pathway-I was the usual monocot somatic embryogenesis type, while pathway-II was unusual, in that the development of somatic embryogenesis proceeded via a large cell cluster-like proembryo. Another line of cells (W-line) did not show any indications of morphogenesis when cultured under the same conditions as Y-line cells. This is the first report of the existence of two pathways for somatic embryogenesis in Allium species.
\end{abstract}

Two developmental processes occur during plant regeneration from cultured cells, organogenesis and somatic embryogenesis. Organogenesis is the process by which cells and tissues are forced to undergo changes that lead to the production of a unipolar structure, namely a shoot or root primordium. In contrast, somatic embryogenesis leads to the production of a bipolar structure containing a root/shoot axis with a closed independent vascular system (Thorpe 1994). Studies on somatic embryogenesis have mainly been done using dicots, only a few have been done using monocots other than Oryza sativa (Genovesi and Magill 1982) and Elymus canadensis (Park and Walton 1989).

There have been several reports on the morphogenesis of cultured cells of several monocot $\mathrm{Al}$ lium species including A. sativum (Abo El-Nil 1977, Nagasawa and Finer 1988, Koch et al. 1995), A. tuberosum (Chandel et al. 1992, Matsuda and Adachi 1996), A. cepa (Phillips and Luteyn 1983, Eady et al. 1998, Luthar and Bohanec 1999), A. fistulosum $\times$ A. cepa (Lu et al. 1989) and A. fistulosum (Shahin and Kaneko 1986, Phillips and Hubstenberger 1987, Van der Valk et al. 1992, Kim and Soh 1996). According to these reports, the regenerated plantlets were all obtained through somatic embryogenesis, although most of them did not provide details about the regeneration pathway from cultured cells. We have previously reported on the chromosomal variations of cultured $A$. fistulosum cells and their subsequent regenerants (Lee and Ono 1999), however, a detailed description on the morphogenesis of the cultured cells was not included. The purpose of this study is to observe morphologically and histologically the process of plant regeneration from cultured A. fistulosum cells and to clarify the regeneration pathway.

Materials and methods

\section{Plant material}

Calli and suspension-cultured cells of Allium fistulosum L. cv. Fresh were used in this study. These cultured cells were established from aseptic seedlings in 1998 (Lee and Ono 1999). 


\section{Culture conditions}

The solid medium for callus subculture consisted of MS salts and vitamins (Murashige and Skoog 1962) containing 3\% sucrose, $0.5 \mathrm{mg} / 1$ 2,4-dichlorophenoxyacetic acid (2,4-D) and $0.3 \%$ Gellan Gum (Kelco, Division of Merck and Co., Inc.). The liquid medium for morphogenesis of cultured cells was identical to the solid medium except for the removal of 2,4-D and Gellan Gum. The suspension culture was established from callus culture with an inoculum of $3 \mathrm{~g}$ fresh weight in a $300-\mathrm{ml}$ Erlenmeyer flask containing $100 \mathrm{ml}$ of MS liquid medium with shaking at $110 \mathrm{rpm}$ and $25^{\circ} \mathrm{C}$ in continuous light $(2000 \mathrm{~lx})$. Cells in suspension were routinely subcultured at 14-day intervals by pouring $3 \mathrm{~g}$ fresh weight of cells into $100 \mathrm{ml}$ of fresh medium. The solid medium to grow somatic embryos consisted of one-tenth diluted MS salts and vitamins, $0.5 \%$ sucrose and no growth regulators. This medium was solidified with $0.3 \%$ Gellan Gum. The $\mathrm{pH}$ of all media was adjusted to 5.7 with $1 \mathrm{M} \mathrm{KOH}$ prior to autoclaving for $20 \mathrm{~min}$.

\section{Histological observations}

The technovit embedding method was used for histological observations. Samples were fixed overnight at $4{ }^{\circ} \mathrm{C}$ in $4 \%$ paraformaldehyde that was buffered with sodium cacodylate (pH 7.2), dehydrated through an ethanol series and then embedded in Technovit 7100 resin (Heraeus Kulzer $\mathrm{GmbH}$ and Co., Wehrheim, Germany). Thin serial sections ( $5 \mu \mathrm{m}$ thick) were cut with a stainless steel blade on an S22 type microtome (Feather Safety Razor Co., Ltd, Japan) and placed on a drop of distilled water on a cover slip and air-dried. To observe the nucleus and DNA, sections were stained with SYBR Green in distilled water and the stained samples were observed using a Nikon ECLIPSE E600 fluorescence microscope. Photographs were taken, using a FUJICHROME Sensia II Film (ASA 100), by the camera which attached at Nikon ECLIPSE E600 fluorescence microscope. Those were directly printed out on Fujifilm Pictrostat Digital 400 (Fuji Photo Film Co., Ltd, Tokyo, Japan). These photographs were taken at magnifications of $\times 100, \times 200$ and $\times 400$.

\section{Results}

\section{Establishment of cell lines}

Two types of callus lines were isolated during subculture, one was a yellowish embryogenic callus line (Y-line) and the other was a white homogeneous callus line (W-line). Y-line calli comprised $87.2 \%$ (218 yellowish callus clumps/250 total callus clumps), while the rate of W-line calli was $12.8 \%$ ( 32 white callus clumps/250 total callus clumps). Somatic embryos were only formed from the Y-line cells when calli from these two lines were transferred to the morphogenesis-inducing medium. The Y-line cells were transferred to fresh liquid medium and the Y-line suspension culture cells were established. This cell line was then used to examine the process of morphogenesis in cultured cells.

\section{Morphogenesis of Y-line cells}

We first observed the external changes that occurred during the morphogenesis of Y-line cells. Consequently, we found that there are two pathways, pathway-I and pathway-II, for the somatic embryogenesis of Y-line cells. The rate of somatic embryogenesis through pathway-I was $82.1 \%$ (69 regenerated plantlets in pathway-I/84 total regenerated plantlets) and that through pathway-II was $17.9 \%$ (15 regenerated plantlets in pathway-II/84 total regenerated plantlets). In pathway-I, globular embryos resulted after 10 days of culture when embryogenic small cell-clusters were transferred to the morphogenesis medium (Fig. 1A). They progressed through several distinct structural phases including oval, barrel (Fig. 1B), banana (Fig. 1C), cotyledonary (Fig. 1D) and mature stages. These steps are characteristic of somatic embryogenesis in monocots.

In pathway-II, after transfer to the morphogenesis-inducing medium, a small cell cluster con- 

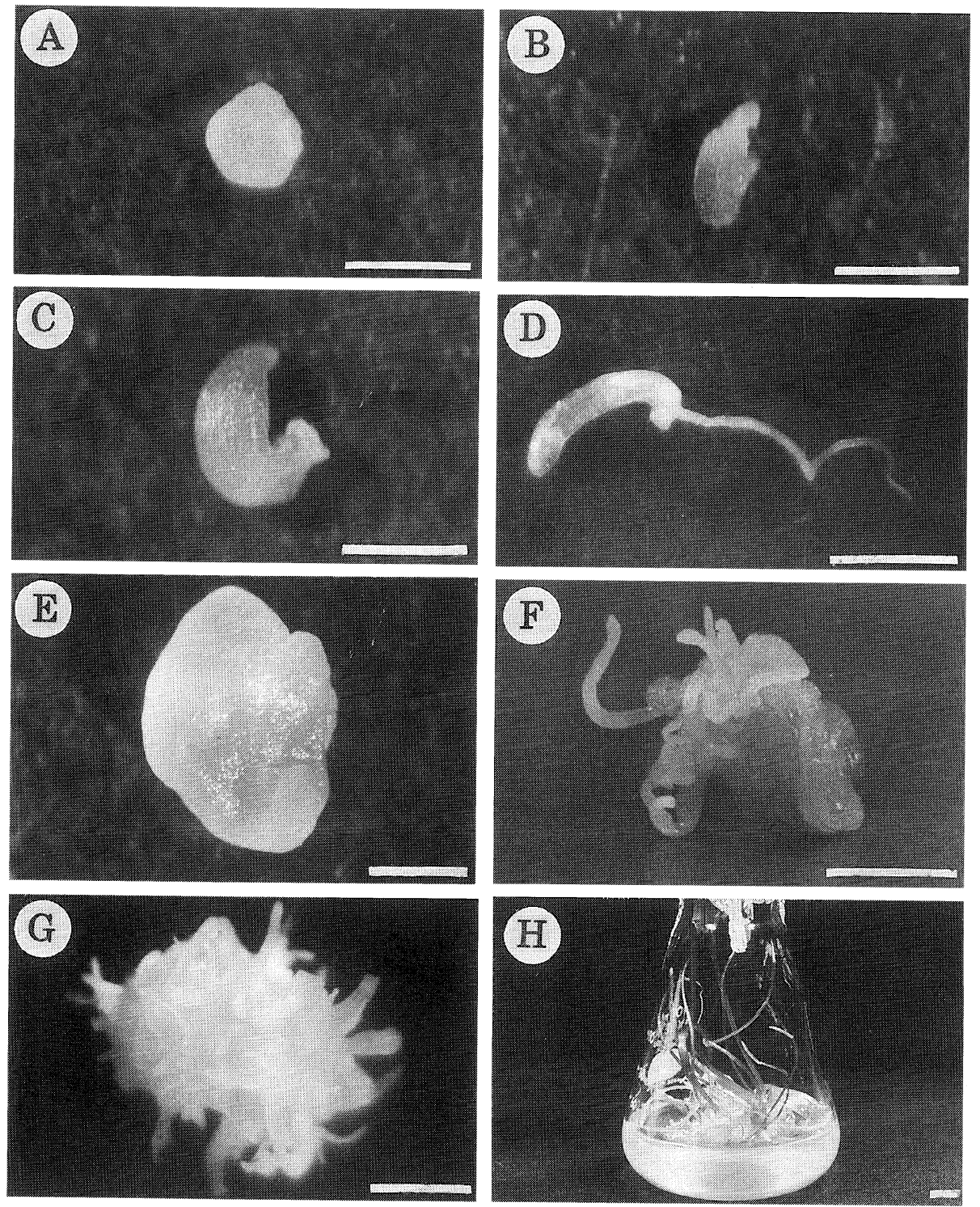

Fig. 1. The process of plant regeneration from A. fistulosum cultured cells. Pathway-I is A-D) and pathway-II is E-G). A) globular embryo 10 days after subculture, B) barrel embryo after 14 days, C) banana embryo after 18 days, D) cotyledonary embryo after 22 days, E) proembryo after 14 days, F) secondary somatic embryos after 20 days, G) many developed cotyledons after 27 days, H) regenerated plantlets after 40 days. Bars indicate $2 \mathrm{~mm}$ in A-E, $1 \mathrm{~cm}$ in F, $\mathrm{H}$ and $5 \mathrm{~mm}$ in G.

tinued to divide and developed into a large, cell-cluster-like proembryo surrounded by epidermis 14 days after subculture (Fig. 1E). The developed cluster soon formed many secondary somatic embryos in its periphery zone 20 days after subculture. Each secondary somatic embryo developed into a cotyledonary embryo after joining pathway-I (Fig. 1F, G). Cotyledonary embryos resulting from both pathway-I and II formed adventitious roots and then developed into plantlets 40 days after culture (Fig. 1H). Another cell line (W-line) did not show any indications of morphogenesis when cultured under the same conditions as Y-line cells.

We next observed histologically the process of somatic embryo development using technovitembedding and SYBR-staining. In pathway-I, a small cell cluster with nuclei stained with SYBR 

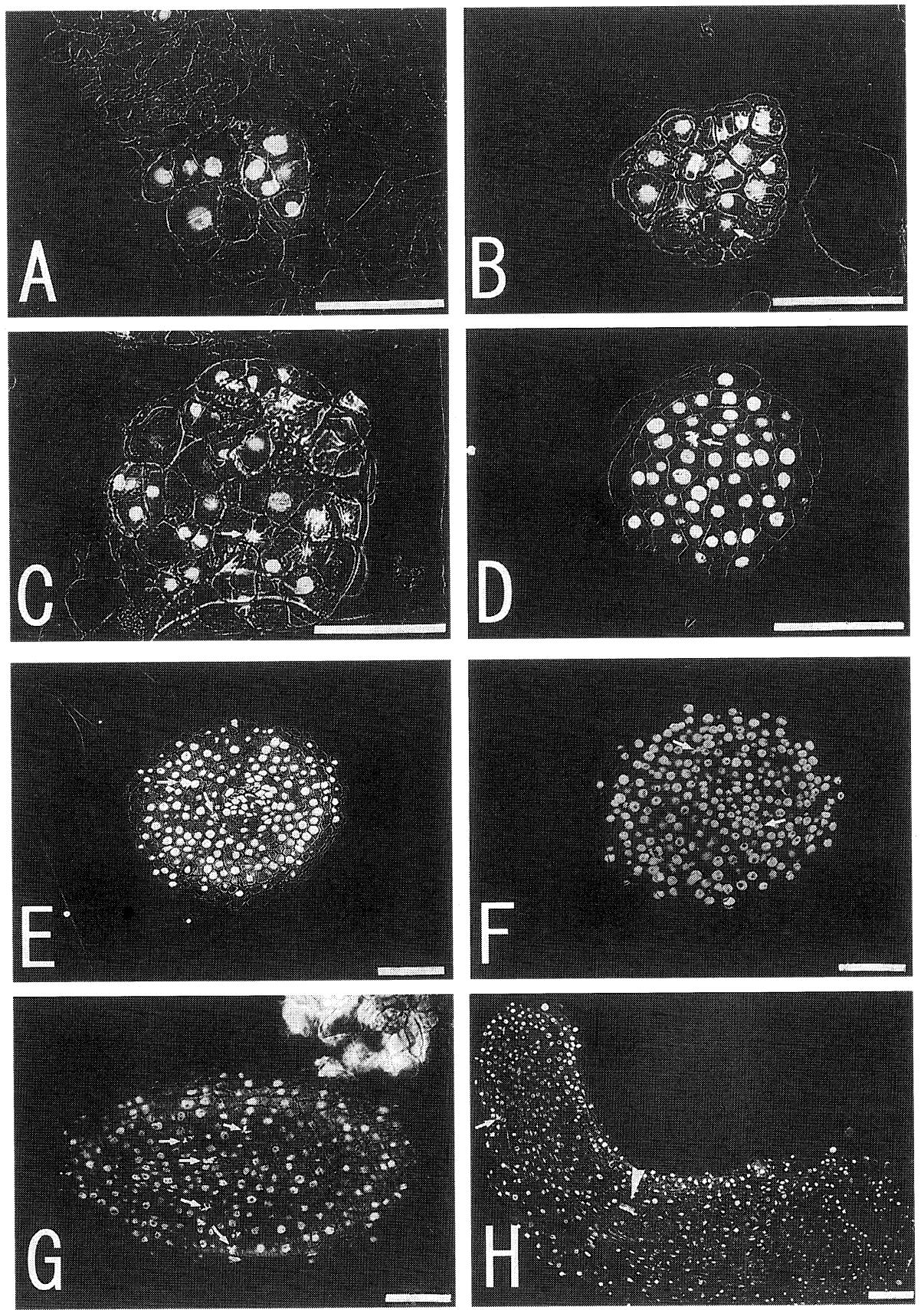

Fig. 2. Pathway-I of somatic embryo development observed with fluorescence fields. Sections through A-D) cell clusters, E) and F) globular embryos, G) barrel embryo, H) banana embryo. A) 2 days, B) 4 days, C) 7 days, D) 9 days, E) 11 days, F) 12 days, G) 14 days, H) 18 days after subculture. Arrows indicate mitotic chromosomes and arrowhead indicates vascular system. Bars indicate $0.1 \mathrm{~mm}$.

Green appeared two or three days after transfer to the morphogenesis medium (Fig. 2A-D). After 11 days, the cell cluster increased in size and cell number by active cell division and developed into a globular embryo (Fig. 2E, F). During these stages, chromosomes in actively dividing cells were sometimes observed in the embryo tissues (Fig. 2B-H). Histological observations confirmed that the globular embryo developed progressively into oval, barrel (Fig. 2G), banana (Fig. 2H) and 

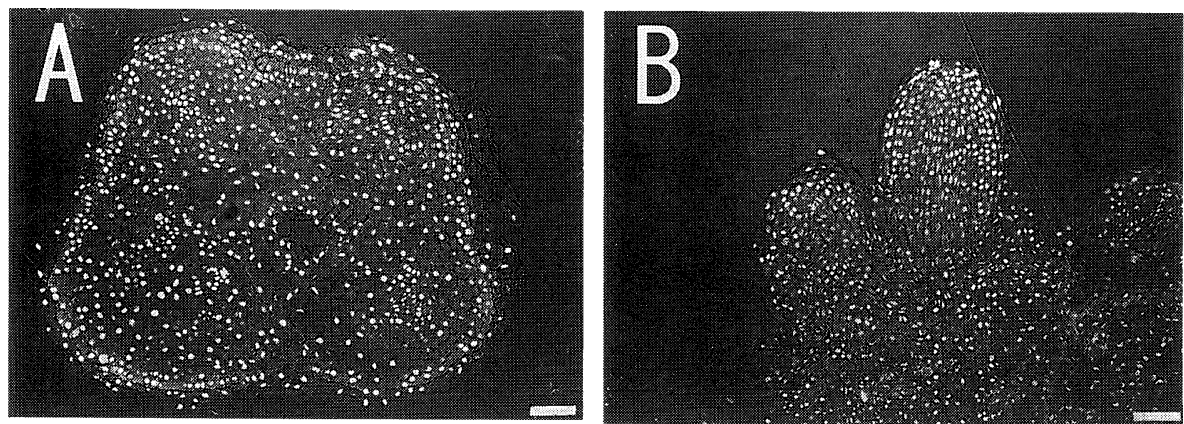

Fig. 3. Pathway-II of somatic embryo development observed with fluorescence fields. Sections through A) proembryo, and B) secondary somatic embryos regenerated from proembryo. Bars indicate $0.1 \mathrm{~mm}$.

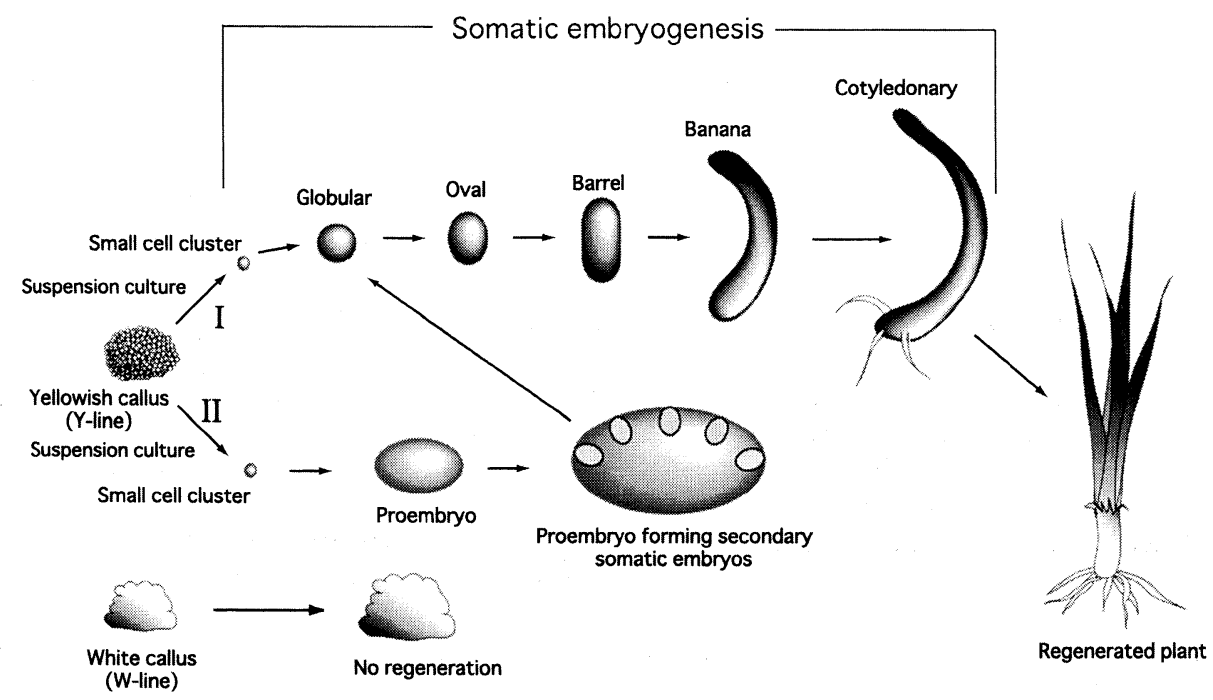

Fig. 4. Morphogenetic pathways in A. fistulosum cultured cells.

cotyledonary embryos. Vascular systems began to appear from banana stage embryos (Fig. $2 \mathrm{H}$ ).

In pathway-II, on the other hand, a proembryo resulted from a small cell cluster (Fig. 3A) and secondary somatic embryos formed at its periphery (Fig. 3B). A secondary somatic embryo then developed into a plantlet after joining pathway I.

\section{Discussion}

There have been reports on the morphogenesis of cultured cells in several Allium species, such as A. sativum, A. cepa and A. fistulosum (Song and Peffley 1994, Koch et al. 1995, Luthar and Bohanec 1999 and others). These studies reported that plant regeneration from cultured cells occurred through somatic embryogenesis, although detailed morphological and histological observations of the process were not presented. The morphogenetic processes of cultured A. fistulosum cells in particular have not been clarified. We previously reported that morphogenesis from A. fistulosum callus cells may proceed by organogenesis with the formation of adventitious shoots and roots in calli (Lee and Ono 1999).

This study proves that there are two-pathways (pathway-I, pathway-II) for the development of A. fistulosum somatic embryogenesis (Fig. 4). Pathway-I is the common process, in which a small 
cell cluster from Y-line cells divides and develops into a plantlet through the distinct embryogenic stages characteristic of monocots. This agrees with results reported previously by Kim and Soh (1996). On the other hand, pathway-II is exceptional, in that a small cell cluster divides and develops into a proembryo in which secondary embryos are formed. These secondary embryos then join pathway-I and develop into plantlets. Secondary embryo formation from a proembryo or primary embryo was reported during callus culture of Beta vulgaris (D'Halluin and Keimer 1986) and hypocotyl culture of Helianthus annuus (Pelisser et al. 1990) but it has not been reported in monocots. The expression lag of genes inducing somatic embryogenesis may cause occurrence of two pathways in the same cell line. That is, the genes affect cells through pathway-II behind those through pathway-I, then cells through pathway-II develop to make proembryos and secondary embryos.

In this study we used technovit embedding and SYBR Green staining to confirm that the morphogenesis of cultured Allium fistulosum cells proceeds via two embryogenesis pathways.

\section{Acknowledgements}

The authors are grateful to Dr. H. Takano, Kumamoto University, for his help and advice.

\section{References}

Abo El-Nil, M. M. 1977. Organogenesis and embryogenesis in callus cultures of garlic (Allium sativum L.). Plant Sci Lett. 9: 259-264.

Chandel, K., Ruchira, P. S. and Rama Rao, S. 1992. In vitro propagation of Allium tuberosum Rottl. ex Spreng. by shoot proliferation. Plant Cell Rep. 11: 211-214.

D'Halluin, K. and Keimer, B. 1986. Production of Haploid Sugarbeets (Beta vulgaris L.) by Ovule Culture. In: Horn, W., Jensen, C. J., Odenbach, W. and Schieder, O. (eds.). Genetic Manipulation in Plant Breeding. Proceedings of the International Symposium Organized by EUCARPIA September 8-13, 1985, Berlin. pp. 307-309.

Eady, C. C., Butler, R. C. and Suo, Y. 1998. Somatic embryogenesis and plant regeneration from immature embryo cultures of onion (Allium cepa L.). Plant Cell Rep. 18: 111-116.

Genovesi, A. D. and Magill, C. W. 1982. Embryogenesis in callus derived from rice microspores. Plant Cell Rep. 1: 257-260.

Kim, J. W. and Soh, W. Y. 1996. Plant regeneration through somatic embryogenesis from suspension cultures of Allium fistulosum L. Plant Sci. 114: 215-220.

Koch, M., Tanami, Z. and Salomon, R. 1995. Improved regeneration of shoots from garlic callus. Hort. Sci. $30: 378$.

Lee, K. S. and Ono, K. 1999. Chromosomal variation in callus lines and regenerated plantlets from three cultivars of Allium fistulosum L. $(2 \mathrm{n}=16)$. Cytologia 64: 465-478.

Lu, C. C., Currah, L. and Peffley, E. B. 1989. Somatic embryogenesis and plant regeneration in diploid Allium fistulosum $\times$ A. cepa $\mathrm{F}_{1}$ hybrid onion. Plant Cell Rep. 7: 696-700.

Luthar, Z. and Bohanec, B. 1999. Induction of direct somatic organogenesis in onion (Allium cepa L.) using a two-step flower or ovary culture. Plant Cell Rep. 18: 797-802.

Matsuda, Y. and Adachi, T. 1996. Plant regeneration via embryogenesis in commercial cultivars of Chinese chive (Allium tuberosum Rottl.). Plant Sci. 119: 149-156.

Murashige, T. and Skoog, F. 1962. A revised medium for rapid growth and bioassays with tobacco tissue cultures. Physiol. Plant. 15: 473-497.

Nagasawa, A. and Finer, J. J. 1988. Development of morphogenic suspension culture of garlic (Allium sativum L.). Plant Cell Tissue Organ Cult. 15: 183-187.

Park, C. H. and Walton, P. D. 1989. Embryogenesis and plant regeneration from tissue culture of Canada wild rye, Elymus canadensis L. Plant Cell Rep. 8: 289-291.

Pelissier, B., Bouchefra, O., Pepin, R. and Freyssinet, G. 1990. Production of isolated somatic embryos from sunflower thin cell layers. Plant Cell Rep. 9: 47-50.

Phillips, G. C. and Hubstenberger, J. 1987. Plant regeneration in vitro of selected Allium species and interspecific hybrids. Hort. Sci. 22: 124-125.

- and Luteyn, K. L. 1983. Effects of picloram and other auxins on onion tissue cultures. J. Am. Soc. Hort. Sci. 108: 948-953. 
Shahin, E. A. and Kaneko, K. 1986. Somatic embryogenesis and plant regeneration from callus cultures of nonbulbing onions. Hort. Sci. 21: 294-295.

Song, P. and Peffley, E. B. 1994. Plant regeneration from suspension cultures of Allium fistulosum and A. fistulosum $\times$ A. cepa interspecific hybrid. Plant Sci. 98: 63-68.

Thorpe, T. A. 1994. Morphogenesis and Regeneration. In: Vasil, I. K. and Thorpe, T. A. (eds.). Plant Cell and Tissue Culture. Kluwer Academic Publishers. pp. 17-36.

Van der Valk, P., Scholten, O. E., Verstappen, F., Jansen, R. C. and Dons, J. J. M. 1992. High frequency somatic embryogenesis and plant regeneration from zygotic embryo-derived callus cultures of three Allium species. Plant Cell Tissue Organ Cult. 30: 181-191. 